remains to be established. One line of investigation could be to find out whether in patients suffering from hiccup, drugs with dopamine-like action, such as apomorphine, will increase this disturbance.-I am, etc.,

A. D. KoRCZYN

Beilinson Hospital,

Tel Aviv University Medical School,

Israel

1 Davis, J. N., Brain, 1970, 93, 851.

SIR,-Your leading article entitled "Hiccup" (1 May, p. 234) takes me back to 1936 , when I was a house physician in the Royal Infirmary of Edinburgh and a patient was admitted almost in extremis with continuous hiccup. My chief ordered $5 \mathrm{ml}$ of $25 \%$ magnesilum sulphate solution intramuscularly into the upper and outer quadrant of the buttock twice daily for two days and once daily to complete five days. The hiccup was soon reduced in frequency and disappeared completely after around 36 hours.

A chest radiograph revealed chronic pulmonary tuberculosis with cavitation, and the sputum was positive for $M$. tuberculosis. I am, etc.,

JOHN MACKAY-Dick

Edinburgh

SIR,-In your leading article on Hiccup (1 May, p. 234) you quote Douthwaite as suggesting amitriptyline to treat persistent hiccup. In fact, in his letter to the Lancet Dr. Douthwaite commends metoclopramide (Maxolon) as being useful in some cases.-I am, etc.,

T. W. Calvert

Middlesex Hospital,

London $W .1$

Douthwaite, A. H., Lancet, 1968, 1, 144.

${ }_{*}^{*}$ Dr. Calvert is quite right.-ED., B.M.f.

\section{Depressive Illness in Children}

SIR,-Your leading article on "Depressive Illness in Children" ( 1 May, p. 237) is indeed apposite when it refers to "parental hostility, rejection (and) distorted family relationships" as causes of such illness. My own feeling, however, is that children subjected to this form of planned psychological abuse tend to show up later as anti-social deviants rather than depressives.

On the other hand, there is a good dea of psychological abuse which shows no outward evidence but which must damage the child emotionally. It is more than emotional deprivation by default or neglect-it is an actively pursued policy of systematic emotional sadism. I often hear of these cases through social rather than professional channels and thus get the impression that they occur largely in social classes 1 and 2, which may or may not be correct. Physical abuse, of course, occurs at all social levels though Helfer and Kempe $^{1}$ infer that it may be more common at the lower levels, possibly due to environmental factors.

In the typical case, father is in one of the professions, a church office-bearer, and a member of Rotary and of the "right" golf club, while mother had a rewarding career before marriage and does good works through the W.R.V.S. or Red Cross, being a member of the Bridge Club, Ladies' Circle, etc. More often than not the health visitor does not call because "it is such a good home and the parents do not consider my visits are necessary." Yet it is these parents (together or one with the approval or condonation of the other) who carry out a planned campaign of psychological abuse of a child or children which would shame an interrogator in a police state. The child's life is a bewildering tangle of broken promises, false hopes, frustrated anticipations and wilful misleadings unil he is a seething cauldron of impotent rage. Surely this must cause emotional damage.

In this nebulous field, however, it is difficult to get "hard data." In the community it is difficult to gauge the extent to which it occurs, while in hospital it must be difficult for the child or adolescent psychiatrist to unravel it in case history taking, when the child himself may not even be aware of the extent to which his parents' behaviour is abnormal. Again, some of the more resilient children (and the resilience of children never ceases to astonish me) may survive scarred, but not permanently damaged and never be seen by a psychiatrist at all. Or they may become the drop outs, the misfits, the odd balls whose lives are a pattern of cynicism and mistrust.-I am, etc.

County Health Department,

H. D. WILSON Haddington

\section{East Lothian}

1 Helfer, R. E., and Kempe, C. F., The Battered Child. Chicago, University of Chicago Press, 1968.

\section{Post-Hypoglycaemic Encephalopathy}

SIR,-I was interested in Mr. D. C. Dunn's article (10 April, p. 84) because although mainly dealing with the late effects of removal of islet cell tumours of the pancreas, it touches upon the facts and problems of post-hypoglycaemic encephalopathy. Mr. Dunn reports cases of mental deterioration from the literature on sequelae of insuloma operations-hypoglycaemia having had a similar effect to anoxia-but stresses the prima facie "normality" of his follow-up cases (in spite of reduced insulin production), apart from two neurological complications.

On further consideration, the situation may be still more complicated by a further factor. We know from the study of persons with "minimal brain damage" (or "marginal encephalopathies" as I have called them) that their main difference compared with other people lies in their response to stress. ${ }^{1}$ Generally speaking, some functional properties of the central nervous system will reveal themselves best under provocation (in the E.E.G. field one speaks of "evoked responses"). This holds good both for the neurophysiological as well as the psychological aspects of the constitutional torality of a person. Mr. Dunn already indicates mild E.E.G. abnormalities resembling "minimal brain damage" in a number of cases. It is furthermore a characteristic of "marginal encephalopathies" that they are predisposed to neurotic reactions under stress.

My experimental investigations into sensory stress response-for example, using the flicker fusion technique and automatic responses recorded on a polygraph ${ }^{2}$-indicate that this type of stress response is constitutionally determined and therefore "differential" as between types. We have to include here the possibility of a functional alteration of the nervous constitution. Far be it from me to regard persons with minimal brain damage as "abnormal," but their response to stress can easily be "different." In conclusion, it can be said that the "stress response" consideration is bound to widen the outlook in this field.-I am, etc.,

Reading

STEPHEN KRAUSS

1 Krauss, S., in Proceedings of the 8th International 2 Congress of Neurology, Vienna, 1965, 5, 145. Congress of Applied Psychology, Liège, 1971, in
Couss, in Proceedines of the 17th International press.

\section{Suicide and Euthanasia}

SIR,-The present position in Switzerland is that "any person who, for selfish motives, incites someone to suicide or renders him assistance in this, will, if the suicide is perpetrated or attempted, be punished with penal servitude for up to five years or prison."1 In the case of a patient dying of incurable and painful disease there would be no question of selfish motives, nor would there be incitement though there might be assistance in carrying out the patient's wishes.

One senses from Reverend H. C. Trowell's more tolerant reaction (1 May, p. 275) to a modification of our own Suicide Act (1961) along these lines as a means of introducing voluntary euthanasia that he, like many others, finds an active involvement in the termination of life the really repugnant feature. It might be another matter if the patient (in one of the categories envisaged by the advocates of voluntary euthanasia) were to be given the facility to ask for death and the means to achieve it. The safeguards proposed by Lord Raglan's Bill [see B.M.f., 15 March 1969, p. 725] would continue to apply. The only difference would be that the doctor, having provided the fatal potion, would not even need to be present.

A correlative issue is the question of the resuscitation of potential suicides. It is axiomatic today that suicide is the act of a disordered mind. Society clings to the belief that life, however painful, however undesired by the subject, must always be preferable to death. While admiring the work of psychiatrists, Samaritans, etc., who are able to salvage so many, is it not possible that efforts in this direction can be overzealous, comparable to over-active treatment of terminal disease?

The philosophical acceptance of death as a merciful episode, rather than as an ultimate catastrophe, is an element of wisdom which medical practice appears to have lost as a result of the enormous powers modern science has provided, powers themselves linked with an ultimately non-Christian and materialistic society.-I am, etc.,

\section{S. L. HENDERSON SMITH}

Huddersficlu, Yorks

1 Swiss Criminal Code, 1937, Article 115.

\section{Keeping it in the Family}

SIR,-As a medical student from a nonmedical family I wish to reply to the remarks of Dr. John McKee in his "Personal View" (15 May, p. 397) that "all doctors' offspring with reasonable academic standards" should be accepted for medicine before others with 